\title{
Pembelajaran Kooperatif Tipe Stad Sebagai Upaya Peningkatan Pemahaman Konsep Matematika Melalui Pendekatan Problem Posing Pada Siswa Kelas VIII MTS Ponpes Alkhairaat Paguat Tahun Pelajaran 2018/2019
}

\author{
Haira Tahir \\ Mts Ponpes Alkhairaat Paguat \\ Hairatahir@Gmail.Com
}

Received: 13 August 2021; Revised: 02 October 2021; Accepted: 14 December 2021

DOI: http://dx.doi.org/10.37905/aksara.8.1.449-460.2022

\begin{abstract}
Abstrak
Penelitian ini merupakan Penelitian Tindakan Kelas yang bertujuan untuk meningkatkan pemahaman konsep matematika siswa dalam pembelajaran matematika melalui pendekatan problem posing dengan pembelajaran kooperatif tipe STAD pada siswa kelas VIII MTs Ponpes Alkhairaat Paguat. Hasil penelitian ini adalah (1) Pembelajaran matematika melalui pendekatan problem posing dengan pembelajaran kooperatif tipe STAD yang dapat meningkatkan pemahaman konsep matematika siswa kelas VIII MTs Ponpes Alkhairaat Paguat: peneliti menginformasikan tujuan dan motivasi, peneliti menginformasikan topik pembelajaran, siswa diberi contoh membuat soal, siswa berkelompok menurut kemampuan siswa di dalam kelas, siswa berdiskusi untuk membuat soal dan penyelesaiannya sesuai situasi yang ada dalam student worksheet dengan pengawasan, siswa mempresentasikan hasil diskusi, siswa menyimpulkan materi yang dipelajari, siswa mengerjakan kuis yang diberikan secara mandiri, dan memberikan penghargaan kepada kelompok sesuai predikat masing-masing.(2) Rata-rata persentase indikator pemahaman konsep matematika berdasarkan analisis hasil tes siklus 1 dan tes siklus 2 mengalami peningkatan sebesar 13,22\% yaitu pada siklus 1 sebesar 70,40\% dan meningkat menjadi $83,62 \%$ pada siklus 2 dan termasuk kategori tinggi. (3) Rata-rata persentase indikator pemahaman konsep matematika kelompok berdasarkan hasil analisis student worksheet mengalami peningkatan sebesar $3,34 \%$ dari siklus 1 ke siklus 2 yaitu dari 78,63\% menjadi 81,97\% dan termasuk dalam kategori tinggi. (4) Persentase ketuntasan belajar siswa mengalami peningkatan sebesar $22 \%$ yaitu pada siklus 1 sebesar $42 \%$ dan meningkat menjadi $64 \%$ pada siklus 2 .
\end{abstract}

Kata Kunci: Pembelajaran Kooperatif Tipe STAD, Pendekatan Problem Posing

\section{PENDAHULUAN}

Pendekatan problem posing dapat dilaksanakan dengan model pembelajaran kooperatif. Menurut Anita Lee (2004: 29-31), model pembelajaran kooperatif merupakan suatu model pembelajaran yang mengutamakan adanya kelompokkelompok belajar yang di dalamnya menekankan kerjasama. Ada unsur-unsur dasar dalam cooperative learning yang membedakannya dengan pembagian kelompok yang dilakukan asal-asalan. Unsur-unsur tersebut adalah saling ketergantungan positif, tanggung jawab perseorangan, tatap muka, komunikasi antarangota dan evaluasi proses kelompok. Model pembelajaran ini dapat membantu para siswa meningkatkan sikap positif siswa dalam matematika, meningkatkan berfikir kritis, meningkatkan kemampuan siswa dalam pemecahan masalah serta meningkatkan pemahaman terhadap materi yang dihadapi atau didiskusikan.

Salah satu tipe dari cooperative learning adalah STAD (Student Teams Achievement Divisions). Gagasan utama dari STAD adalah untuk memotivasi siswa supaya dapat 
saling mendukung dan membantu satu sama lain dalam menguasai kemampuan yang diajarkan oleh guru. Pembelajaran yang menggunakan STAD diawali dengan pembagian siswa ke dalam kelompok belajar yang terdiri atas 4-5 orang. Setelah guru menyampaikan pelajaran, siswa bekerja dalam kelompok untuk memastikan semua anggota tim telah menguasai pelajaran. Selanjutnya, semua siswa mengerjakan kuis secara individual. Skor kuis ini akan dibandingkan dengan rata-rata pencapaian sebelumnya dan pada setiap kelompok akan diberikan poin berdasarkan tingkat kemajuan yang diraih. Rata-rata skor tim yang memenuhi kriteria tertentu akan mendapatkan penghargaan (Slavin, Robert E, 2009: 11-12).

Pembelajaran melalui problem posing dengan cooperative learning tipe STAD (Student Teams Achievement Divisions) ini merupakan pembelajaran dimana siswa secara berkelompok membuat soal dan menyelesaikannya sesuai dengan konsep materi yang telah dipelajari kemudian dilanjutkan dengan kuis untuk memperoleh skor kemajuan individual. Setiap selesai penyampaian materi, guru memberikan contoh tentang cara pembuatan soal kemudian siswa berkelompok untuk membuat soal.

Permasalahan yang terjadi pada pembelajaran Matematika di MTs Ponpes Alkhairaat Paguat berdasarkan refleksi awal ditemui data sebagai berikut. Dari faktor siswa, sebagian besar siswa belum sepenuhnya bertanggungjawab untuk memperhatikan materi pelajaran yang sedang diajarkan, sebagian siswa justru asik berbicara dengan teman sebangkunya dan mengganggu teman lainnya. Akibatnya, siswa kurang memahami materi pelajaran yang diajarkan. Selain itu, sebagian besar siswa masih terlihat pasif dan kurang antusias, serta kurang termotivasi dalam mengikuti pembelajaran. Sedangkan dari faktor Kegiatan Belajar Mengajar (KBM), suasana pembelajaran yang tercipta kurang kondusif, hal tersebut ditunjukkan dengan proses belajar mengajar yang kurang interaktif antara guru dan siswa, sehingga pembelajaran yang berlangsung terkesan hanya satu arah. Dari berbagai permasalahan yang terjadi menyebabkan hasil belajar Matematika pada siswa kelas VIII MTs Ponpes Alkhairaat Paguat kurang maksimal. Dalam pembelajaran beberapa siswa masih sulit untuk benar-benar memahami konsep matematika yang dijelaskan, hal ini ditunjukkan dengan :

1. Beberapa siswa belum dapat mengklasifikasikan obyek-obyek menurut sifatsifat penjumlahan dan pengurangan bentuk aljabar karena ada yang menjumlahkan sukusuku tidak sejenis.

2. Beberapa siswa masih kesulitan menggunakan dan memilih prosedur tertentu karena masih ada siswa yang kesulitan menyederhanakan bentuk aljabar.

3. Beberapa siswa kesulitan dalam mengurangkan dan menjumlahkan bentuk aljabar karena kurang menguasai konsep penjumlahan dan pengurangan pada bilangan bulat.

4. Siswa masih kesulitan saat mengerjakan soal mengenai aplikasi aljabar. Beberapa diantaranya kesulitan karena kurang menguasai perkalian binomial.

Pembelajaran yang dilaksanakan masih menggunakan metode ceramah sehingga siswa kurang aktif dalam pembelajaran. Siswa tidak dilatih untuk membuat soal sendiri dan berdiskusi dalam kelompok. Hal ini menunjukkan bahwa peneliti belum menggunakan pendekatan problem posing maupun cooperative learning dalam pembelajaran

Berdasarkan permasalahan pembelajaran di atas, peneliti menetapkan alternatif tindakan untuk melakukan penelitian mengenai pembelajaran kooperatif tipe STAD 
sebagai upaya peningkatkan pemahaman konsep matematika melalui pendekatan problem posing pada siswa kelas VIII MTs Ponpes Alkhairaat Paguat.

Adapun tujuan penelitian tindakan kelas ini adalah meningkatkan pemahaman konsep matematika melalui pendekatan problem posing pada siswa kelas VIII MTs Ponpes Alkhairaat Paguat.

\section{KAJIAN TEORITIS}

Dalam pembelajaran matematika, siswa tidak hanya menghafal fakta dan teori saja, namun diarahkan pada pemahaman konsep-konsep matematika atas dasar pemikiran yang logis, rasional dan sistematis. Guru hendaknya dapat menyajikan pembelajaran yang efektif dan efisien, sesuai dengan kurikulum dan pola pikir siswa untuk mengembangkan kreatifitas dan kompetensi siswa.

Pemahaman konsep matematika adalah kemampuan bersikap, berpikir dan bertindak yang ditunjukkan oleh siswa dalam memahami definisi, pengertian, ciri khusus, hakikat dan inti /isi dari materi matematika dan kemampuan dalam memilih serta menggunakan prosedur secara efisien dan tepat. Pemahaman konsep materi prasyarat sangat penting untuk memahami konsep selanjutnya. Selain itu pemahaman konsep dapat digunakan untuk menggeneralisasikan suatu obyek. Konsep matematika harus diajarkan secara berurutan. Hal ini karena pembelajaran matematika tidak dapat dilakukan secara melompat-lompat tetapi harus tahap demi tahap, dimulai dengan pemahaman ide dan konsep yang sederhana sampai ke tahap yang lebih kompleks

Pembelajaran melalui pendekatan problem posing merupakan pembelajaran yang lebih menekankan pada kegiatan menemukan permasalahan yang sifatnya agak kompleks dalam bentuk soal yang dilakukan oleh siswa sendiri. Dalam proses pembelajarannya, siswa diarahkan untuk mengkaji situasi masalah yang diberikan misalnya berupa diagram, gambar, benda tiruan, atau informasi tertulis. Berdasarkan situasi yang diberikan pada siswa, guru membimbing dan melatih siswa cara-cara mengajukan masalah melalui berbagai contoh yang bervariasi.

Model pembelajaran kooperatif memiliki beberapa tipe, salah satunya adalah STAD (Student Teams Achievement Divisions). STAD merupakan salah satu metode pembelajaran kooperatif yang bertujuan untuk memotivasi siswa supaya dapat saling mendukung dan membantu satu sama lain dalam menguasai kemampuan yang diajarkan oleh guru. STAD (Student Teams Achievement Divisions) terdiri atas lima komponen utama yaitu:

\section{Presentasi Kelas}

Materi dalam STAD pertama-tama diperkenalkan dalam presentasi di dalam kelas. Ini merupakan pengajaran langsung seperti yang sering dilakukan atau diskusi pelajaran yang dipimpin oleh guru, tetapi bisa juga memasukkan presentasi audiovisual.

2. Tim

Tim terdiri atas empat atau lima siswa yang mewakili seluruh bagian dari kelas dalam hal kinerja akademik, jenis kelamin, ras dan etnisitas. Fungsi utama dari tim adalah memastikan bahwa semua anggota tim benar-benar belajar dan mempersiapkan anggotanya untuk mengerjakan kuis dengan baik.

3. Kuis 
Setelah guru memberikan presentasi dan praktik tim, para siswa akan mengerjakan kuis secara individual.

4. Skor Kemajuan Individual

Gagasan dibalik skor kemajuan individual adalah untuk memberikan motivasi kepada tiap siswa mengenai tujuan kinerja yang akan dapat dicapai apabila mereka bekerja lebih giat dan memberikan kinerja yang lebih baik daripada sebelumnya. Tiap siswa diberi skor "awal", yang diperoleh dari rata-rata kinerja siswa tersebut sebelumnya. Siswa selanjutnya mengumpulkan poin untuk tim mereka berdasarkan tingkat kenaikan skor kuis mereka dibandingkan dengan skor awal mereka.

\section{PENDEKATAN PROBLEM POSING DENGAN PEMBELAJARAN KOOPERATIF TIPE STAD}

Pembelajaran melalui pendekatan problem posing dengan cooperative learning tipe STAD (Student Teams Achievement Divisions) ini merupakan pembelajaran yang menekankan pada pembentukan atau perumusan soal oleh siswa secara berkelompok kemudian dilanjutkan dengan kuis untuk mengetahui kemajuan individual dan menentukan skor tim.

Berikut ini adalah langkah-langkah pembelajaran dengan pendekatan problem posing menurut Suryanto (Nursalam, 2008) :

1.Siswa diberi contoh perumusan soal dengan beberapa taraf kesukaran, baik kesulitan isi matematika maupun kesulitan bahasanya.

2.Siswa disediakan beberapa situasi yang berupa informasi tertulis, benda manipulatif, gambar, atau yang lainnya, kemudian siswa berlatih merumuskan soal dengan situasi yang ada.

3.Siswa dimotivasi untuk mengungkapkan pertanyaan sebanyak-banyaknya terhadap situasi yang diberikan.

4.Siswa berlatih menyelesaikan soal-soal yang dirumuskan temannya sendiri.

Sedangkan langkah-langkah penerapan pembelajaran kooperatif tipe STAD menurut Slavin (2009: 151-160) adalah:

1.Siswa mendapat penjelasan mengenai apa yang akan mereka pelajari dan mengapa hal itu penting.

2.Siswa dikenalkan dengan topik pembelajaran sesuai dengan kompetensi yang akan dicapai.

3.Siswa dibagi ke dalam kelompok belajar yang terdiri dari empat atau lima siswa yang mewakili seluruh bagian dari kelas dalam hal kinerja akademik, jenis kelamin, ras, dan etnisitas.

4.Siswa bekerja dalam tim untuk menguasai materi dengan mendiskusikan lembar kegiatan.

5.Siswa mengerjakan kuis secara individual.

6.Setiap kelompok diberi penghargaan berdasarkan perolehan poin kemajuan individual dari skor awal ke skor kuis berikutnya. 


\section{METODE PENELITIAN}

Penelitian ini menggunakan metode PTK yang bertujuan untuk meningkatkan pemahaman konsep matematika dengan menggunakan model pembelajaran Kooperatif tipe STAD dengan pendekatan Problem Posing. Penelitian ini dilaksanakan di kelas VIII MTs Ponpes Alkhairaat Paguat Tahun Pelajaran 2018/2019. Penelitian Tindakan Kelas dilaksanakan dalam 2 siklus.

Instrumen adalah alat yang digunakan untuk mengumpulkan data dalam penelitian. Bentuknya dapat berupa tes tertulis, Student Worksheet, Lembar Observasi dan Dokumentasi.

Teknik pengumpulan data yang digunakan dalam penelitian tindakan kelas ini yaitu 1. Mengadakan Observasi, 2. Melaksanakan Tes akhir siklus dan Tes Prestasi dan 3. Dokumentasi.

Setiap siswa dalam proses belajar dikatakan tuntas apabila memperoleh nilai $>70$ (KKM). Tes kognitif dilakukan setiap akhir siklus yang bertujuan untuk mengetahui hasil belajar siswa. Adapun untuk mengetahui ketuntasan individual maka dapat menggunakan rumus sebagai berikut :

Nilai Akhir $=($ Jumlah jawaban benar $/$ jumlah seluruh soal $) \times 100 \%$

Untuk mengetahui skor rata-rata kelas setiap siklus menggunakan rumus sebagai berikut :

Skor rata-rata $=($ Skor seluruh siswa $/$ jumlah siswa $)$

Ketuntasan klasikal dapat dikatakan telah tercapai apabila nilai siswa memenuhi KKM dengan target pencapaian ideal lebih atau sama dengan $75 \%$ dari jumlah seluruh siswa dalam kelas. Untuk mengetahui ketuntasan secara klasikal dapat menggunakan rumus sebagai berikut :

$\% \mathrm{KKM}=($ Jumlah siswa yang tuntas $/$ jumlah siswa $) \times 100 \%$

\section{HASIL DAN PEMBAHASAN}

\section{Hasil Penelitian Siklus 1}

\section{Perencanaan Siklus 1}

1) Penyusunan Lesson Plan (Rencana Pembelajaran) yang memuat pendekatan problem posing dengan pembelajaran kooperatif tipe STAD (Student Teams Achievement Divisions) dalam kegiatan pembelajarannya.

2) Penyusunan Student worksheet dengan topik pembelajaran Relation dan sub topik pembelajaran.

3) Penyusunan soal tes siklus yang berupa soal uraian dan terdiri dari enam butir soal. Topik pembelajaran tes adalah Relation.

4) Menyusun pedoman observasi pelaksanaan pembelajaran di kelas dengan tujuan mempermudah peneliti dalam melakukan observasi.

5) Penyusunan soal kuis yang berupa soal uraian, dimana siswa diminta membuat soal dan penyelesaiannya berdasarkan informasi yang diberikan.

\section{Pelaksanaan Siklus 1}

1) Data Hasil Observasi

Peneliti mengamati proses pembelajaran matematika di kelas menggunakan lembar observasi yang telah disusun. Berikut adalah tabel hasil analisis observasi 
pembelajaran matematika melalui pendekatan problem posing dengan pembelajaran kooperatif tipe STAD (Student Teams Achievement Divisions) pada siklus 1.

Tabel 1. Analisis Hasil Observasi Pembelajran Matematika

\begin{tabular}{|c|l|l|l|}
\hline \multicolumn{1}{|c|}{ Siklus } & Pertemuan & Persentase & Kualifikasi \\
\hline \multirow{3}{*}{1} & 1 & $88,89 \%$ & Tinggi \\
\cline { 2 - 4 } & 2 & $88,89 \%$ & Tinggi \\
\cline { 2 - 4 } & Rata-rata & $88,89 \%$ & Tinggi \\
\hline
\end{tabular}

Berikut adalah gambaran hasil observasi yang telah dilakukan selama pembelajaran pada siklus 1:

a) $88,89 \%$ langkah-langkah pembelajaran melalui pendekatan problem posing dengan pembelajaran kooperatif tipe STAD (Student Teams Achievement Divisions) terlaksana.

b) Beberapa kelompok berdiskusi tanpa melibatkan seluruh anggota kelompoknya, karena saat diskusi kelompok berjalan masih ada beberapa siswa yang mengobrol dengan temannya dimana topik pembicaraan bukanlah topik pembelajaran dalam student worksheet.

c) Presentasi yang dilakukan oleh siswa tidak mencakup seluruh aktivitas yang ada dalam student worksheet karena terbatasnya waktu.

$\underline{\text { Hasil Tes }}$

Selain mengisi mengisi angket pada akhir pelajaran, peserta didik juga mengerjakan tes dari soal konsep kimia.

Pada pertemuan ketiga dilaksanakan Tes Siklus 1. Berdasarkan nilai tes pada siklus 1 ini, siswa yang mencapai Kriteria Ketuntasan Minimal (KKM) ada 11 siswa atau sebesar $42 \%$ dari jumlah siswa. Tabel 4 menunjukkan persentase pemahaman konsep matematika siswa pada tes siklus 1.

Tabel 2. Persentase Pemahaman Konsep Matematika Siswa pada Tes Siklus 1

\begin{tabular}{|l|l|c|}
\hline No & \multicolumn{1}{|c|}{ Indikator Pemahaman Konsep } & $\begin{array}{c}\text { Persentase Pencapaian } \\
\text { Siklus 1 }\end{array}$ \\
\hline 1 & $\begin{array}{l}\text { Menyatakan ulang sebuah konsep } \\
93,59 \%\end{array}$ \\
\hline 2 & $\begin{array}{l}\text { Mengklasifikasikan objek-objek menurut sifat- } \\
\text { sifat tertentu (sesuai dengan konsepnya) }\end{array}$ & $30,77 \%$ \\
\hline 4 & $\begin{array}{l}\text { Memberi contoh dan non contoh dari konsep } \\
\text { Menyajikan konsep dalam berbagai bentuk } \\
\text { diagram. }\end{array}$ & $91,54 \%$ \\
\hline 5 & $\begin{array}{l}\text { Mengembangkan syarat perlu atau syarat cukup } \\
\text { suatu konsep }\end{array}$ & $48,74 \%$ \\
\hline 6 & $\begin{array}{l}\text { Menggunakan, memanfaatkan, dan memilih } \\
\text { prosedur atau operasi tertentu. }\end{array}$ & $82,05 \%$ \\
\hline 7 & $\begin{array}{l}\text { Mengaplikasikan konsep atau algoritma dalam } \\
\text { pemecahan masalah. }\end{array}$ \\
\hline \multicolumn{2}{|l}{ Rata-rata persentase pemahaman konsep } & $82,05 \%$ \\
\hline
\end{tabular}


Hasil Worksheet

Berdasarkan hasil analisis pengerjaan student worksheet pada siklus 1, diperoleh data tentang pemahaman konsep matematika kelompok siswa kelas VIII MTs Ponpes Alkhairaat Paguat.

Tabel 3. Persentase Pemahaman Konsep Siswa terhadap Student Worksheet siklus 1

\begin{tabular}{|l|l|c|}
\hline No & \multicolumn{1}{|c|}{ Indikator Pemahaman Konsep } & $\begin{array}{c}\text { Persentase } \\
\text { Pencapaian Siklus 1 }\end{array}$ \\
\hline 1 & $\begin{array}{l}\text { Menyatakan ulang sebuah konsep } \\
26,67 \%\end{array}$ \\
\hline 3 & $\begin{array}{l}\text { Mengklasifikasikan objek-objek menurut sifat- } \\
\text { sifat tertentu (sesuai dengan konsepnya) }\end{array}$ & $100 \%$ \\
\hline 4 & $\begin{array}{l}\text { Memberi contoh dan non contoh dari konsep } \\
\text { representasi matematis yaitu dalam bentuk } \\
\text { diagram. }\end{array}$ & $74,58 \%$ \\
\hline 5 & $\begin{array}{l}\text { Mengembangkan syarat perlu atau syarat cukup } \\
\text { suatu konsep }\end{array}$ & $79,67 \%$ \\
\hline 6 & $\begin{array}{l}\text { Menggunakan, memanfaatkan, dan memilih } \\
\text { prosedur atau operasi tertentu. }\end{array}$ & $93,33 \%$ \\
\hline 7 & $\begin{array}{l}\text { Mengaplikasikan konsep atau algoritma dalam } \\
\text { pemecahan masalah. }\end{array}$ & $90 \%$ \\
\hline \multicolumn{2}{|l|}{ Rata-rata persentase pemahaman konsep kelompok } & $78,63 \%$ \\
\hline
\end{tabular}

\section{Refleksi}

Berdasarkan hasil analisis kemampuan pemahaman konsep matematika siswa terhadap hasil tes siklus 1 dapat diketahui bahwa persentase kemampuan pemahaman konsep matematika siswa sebesar 70,40\% dan berdasarkan pedoman kualifikasi hasil pekerjaan tes, persentase tersebut sudah termasuk ke dalam kategori tinggi. Walaupun kemampuan pemahaman konsep matematika siswa sudah termasuk tinggi tetapi dapat diketahui pula bahwa dari ketujuh indikator pemahaman konsep ada tiga indikator yang persentase pencapaiannya belum termasuk dalam kategori tinggi. Ketiga indikator tersebut adalah indikator kedua tentang mengklasifikasikan objek-objek menurut sifatsifat tertentu (sesuai konsepnya), indikator keempat tentang menyajikan konsep dalam berbagai bentuk representasi matematis yaitu dalam bentuk diagram, dan indikator kelima yaitu mengembangkan syarat perlu atau syarat cukup suatu konsep. Peneliti kemudian menganalisa data hasil observasi pelaksanaan pembelajaran untuk perbaikan agar pada siklus 2 persentase pencapaian indikator pemahaman konsep kedua, keempat dan kelima bisa meningkat dan tergolong kategori tinggi seperti indikator pemahaman konsep lainnya. Permasalahan yang muncul selama pembelajaran dan mengakibatkan rendahnya ketiga indikator pemahaman konsep antara lain :

1) Rendahnya persentase pencapaian indikator pemahaman konsep kedua dan kelima disebabkan karena siswa kurang memahami topik pembelajaran yang ada dalam student worksheet.

2) Rendahnya persentase pencapaian indikator pemahaman konsep keempat disebabkan karena diskusi kelompok yang dilakukan dalam menyelesaikan student worksheet 
belum maksimal. Saat diskusi kelompok berlangsung masih ada siswa yang mengobrol dengan temannya dan topik yang dibicarakan bukanlah topik pembelajaran yang ada dalam student worksheet. Selain itu, waktu diskusi yang lebih lama dari waktu yang telah direncanakan menyebabkan presentasi hasil diskusi kelompok belum berjalan secara optimal. Hal ini karena tidak semua aktivitas pada student worksheet sempat dipresentasikan serta didiskusikan dalam forum kelas. Pada saat ada siswa yang presentasi, banyak siswa yang tidak memperhatikan sehingga ketika diminta menyajikan konsep dalam berbagai bentuk representasi matematis yaitu dalam bentuk diagram masih kurang tepat.

Berdasarkan permasalahan di atas, untuk pertemuan pada siklus 2 peneliti merumuskan tindakan-tindakan perbaikan sebagai alternatif pemecahan permasalahan tersebut yang diuraikan sebagai berikut:

1) Peneliti memberikan pengawasan yang lebih pada saat diskusi sehingga semua siswa terlibat dalam pengerjaan student worksheet.

2) Peneliti memberikan batasan waktu yang lebih jelas untuk setiap aktivitas siswa selama proses pembelajaran agar seluruh aktivitas siswa terutama tahap presentasi hasil diskusi kelompok dalam forum kelas bisa terlaksana secara optimal.

3) Peneliti memberikan pengawasan yang lebih pada saat presentasi sehingga sehingga semua siswa memperhatikan dan aktif dalam pembahasan hasil diskusi.

\section{Hasil Penelitian Siklus II \\ Perencanaan Siklus II}

Rancangan tindakan pada siklus 2 ini hampir sama dengan kegiatan pada siklus 1 , akan tetapi telah dilakukan beberapa perbaikan rencana tindakan yang didasarkan pada hasil refleksi siklus 1 memberikan pengawasan yang lebih pada saat diskusi dan presentasi, serta pemberian batasan waktu yang lebih jelas dalam aktivitas siswa. Sedangkan untuk soal tes siklus 2 berupa soal uraian yang terdiri dari 6 butir soal. Topik pembelajaran tes adalah Understanding and Expressing the Function, Calculating the number of possible ways of mapping between two sets, and Understanding one-toone correspondence.

\section{Pelaksanaan Siklus II}

Hasil Pengamatan

Peneliti mengamati proses pembelajaran matematika di kelas menggunakan lembar observasi yang telah disusun. Berikut adalah tabel hasil analisis observasi pembelajaran matematika melalui pendekatan problem posing dengan pembelajaran kooperatif tipe STAD (Student Teams Achievement Divisions) pada siklus 2.

Tabel 4. Analisis Hasil Observasi Pembelajran Matematika

\begin{tabular}{|l|l|l|l|}
\hline \multicolumn{1}{|c|}{ Siklus } & Pertemuan & Persentase & Kualifikasi \\
\hline \multirow{3}{*}{1} & 1 & $94,44 \%$ & Tinggi \\
\cline { 2 - 4 } & 2 & $94,44 \%$ & Tinggi \\
\cline { 2 - 4 } & Rata-rata & $94,44 \%$ & Tinggi \\
\hline
\end{tabular}

Berikut adalah gambaran hasil observasi yang telah dilakukan selama pembelajaran pada siklus 2: 
a) $94,44 \%$ langkah-langkah pembelajaran melalui pendekatan problem posing dengan pembelajaran kooperatif tipe STAD (Student Teams Achievement Divisions) terlaksana.

b) Dengan perhatian lebih yang diberikan peneliti terhadap kelompok yang diskusinya belum berjalan optimal, siswa yang pada siklus 1 tidak begitu terlibat dalam pengerjaan student worksheet pada siklus 2 ini mulai dilibatkan oleh anggota kelompoknya.

c) Presentasi yang dilakukan oleh siswa mencakup seluruh aktivitas yang ada dalam student worksheet.

Hasil Tes

Pada pertemuan ketiga dilaksanakan Tes Siklus 2. Berdasarkan nilai tes pada siklus 1 ini, siswa yang mencapai Kriteria Ketuntasan Minimal (KKM) ada 16 siswa atau sebesar 64\% dari jumlah siswa. Tabel 4 menunjukkan persentase pemahaman konsep matematika siswa pada tes siklus 2 .

Tabel 5. Persentase Pemahaman Konsep Matematika Siswa pada Tes Siklus 2

\begin{tabular}{|c|c|c|}
\hline No & Indikator Pemahaman Konsep & $\begin{array}{l}\text { Persentase Pencapaian } \\
\text { Siklus } 2\end{array}$ \\
\hline 1 & Menyatakan ulang sebuah konsep & $96 \%$ \\
\hline 2 & $\begin{array}{l}\text { Mengklasifikasikan objek-objek menurut sifat- } \\
\text { sifat tertentu (sesuai dengan konsepnya) }\end{array}$ & $69 \%$ \\
\hline 3 & Memberi contoh dan non contoh dari konsep & $92 \%$ \\
\hline 4 & $\begin{array}{l}\text { Menyajikan konsep dalam berbagai bentuk } \\
\text { representasi } \\
\text { diagram. }\end{array}$ & $77 \%$ \\
\hline 5 & $\begin{array}{l}\text { Mengembangkan syarat perlu atau syarat cukup } \\
\text { suatu konsep }\end{array}$ & $84 \%$ \\
\hline 6 & $\begin{array}{l}\text { Menggunakan, memanfaatkan, dan memilih } \\
\text { prosedur atau operasi tertentu. }\end{array}$ & $71 \%$ \\
\hline 7 & $\begin{array}{l}\text { Mengaplikasikan konsep atau algoritma dalam } \\
\text { pemecahan masalah. }\end{array}$ & $96 \%$ \\
\hline \multicolumn{2}{|r|}{ Rata-rata persentase pemahaman konsep } & $83,62 \%$ \\
\hline
\end{tabular}

\section{Hasil WorkSheet}

Berdasarkan hasil analisis pengerjaan student worksheet pada siklus 2, diperoleh data tentang pemahaman konsep matematika kelompok siswa kelas VIII MTs Ponpes Alkhairaat Paguat. 
Tabel 6. Persentase Pemahaman Konsep Siswa terhadap Student Worksheet siklus 2

\begin{tabular}{|l|l|c|}
\hline No & \multicolumn{1}{|c|}{ Indikator Pemahaman Konsep } & $\begin{array}{c}\text { Persentase } \\
\text { Pencapaian Siklus 2 }\end{array}$ \\
\hline 1 & Menyatakan ulang sebuah konsep & $74,24 \%$ \\
\hline 2 & $\begin{array}{l}\text { Mengklasifikasikan objek-objek menurut sifat- } \\
\text { sifat tertentu (sesuai dengan konsepnya) }\end{array}$ & $100 \%$ \\
\hline 3 & $\begin{array}{l}\text { Memberi contoh dan non contoh dari konsep } \\
\text { Menyajikan konsep dalam berbagai bentuk } \\
\text { representasi matematis yaitu dalam bentuk } \\
\text { diagram. }\end{array}$ & $78,75 \%$ \\
\hline 5 & $\begin{array}{l}\text { Mengembangkan syarat perlu atau syarat cukup } \\
\text { suatu konsep }\end{array}$ & $73,33 \%$ \\
\hline 6 & $\begin{array}{l}\text { Menggunakan, memanfaatkan, dan memilih } \\
\text { prosedur atau operasi tertentu. }\end{array}$ & $71,67 \%$ \\
\hline 7 & $\begin{array}{l}\text { Mengaplikasikan konsep atau algoritma dalam } \\
\text { pemecahan masalah. }\end{array}$ & $75,83 \%$ \\
\hline Rata-rata persentase pemahaman konsep kelompok & $81,97 \%$ \\
\hline
\end{tabular}

\section{Refleksi}

Berdasarkan hasil analisis serta uraian di atas, walaupun tidak terjadi peningkatan semua indikator pemahaman konsep siswa pada siklus 1 ke siklus 2 tetapi secara keseluruhan rata-rata pemahaman konsep matematika siswa meningkat dan tergolong dalam kategori tinggi. Oleh karena itu dapat disimpulkan bahwa pembelajaran matematika melalui pendekatan problem posing dengan pembelajaran kooperatif tipe STAD (Student Teams Achievement Divisions) dapat meningkatkan rata-rata persentase pemahaman konsep matematika siswa pada topik pembelajaran relation and function sehingga indikator keberhasilan yang telah ditetapkan pada bab III terpenuhi maka tindakan sudah dapat dihentikan. Rendahnya persentase pencapaian indikator pemahaman konsep kedua dan kelima disebabkan karena siswa kurang memahami topik pembelajaran yang ada dalam student worksheet.

\section{Pembahasan}

Secara umum keterlaksanaan pembelajaran matematika melalui pendekatan problem posing dengan pembelajaran kooperatif tipe STAD (Student Teams Achievement Divisions) pada siklus 1 dan siklus 2 sudah sesuai dengan tahapan pada pedoman observasi pembelajaran dan Lesson Plan yang sudah disusun peneliti sebelumnya. Rata-rata persentase keterlaksanaan pembelajaran pada siklus 1 adalah sebesar 88,89\% dan berdasarkan pedoman kualifikasi persentase tersebut tergolong dalam kategori tinggi. Persentase tersebut meningkat pada siklus II menjadi sebesar 94,44\% dan dan berdasarkan pedoman kualifikasi persentase tersebut tergolong dalam kategori tinggi.

Berdasarkan deskripsi hasil penelitian yang telah diuraikan sebelumnya, diketahui bahwa pelaksanaan pembelajaran matematika melalui pendekatan problem posing dengan pembelajaran kooperatif tipe STAD (Student Teams Achievement Divisions) dapat meningkatkan pemahaman konsep matematika siswa kelas VIII MTs Ponpes Alkhairaat Paguat pada topik pembelajaran relasi dan fungsi. Hal ini berdasarkan data 
yang diperoleh baik melalui hasil tes siklus 1 dan siklus 2 serta hasil analisis student worksheet.

Berdasarkan analisis hasil tes siklus 1 dan tes siklus 2 persentase pemahaman konsep matematika siswa mengalami peningkatan sebesar 13,22\% yaitu pada siklus 1 sebesar $70,40 \%$ dan meningkat menjadi $83,62 \%$ pada siklus 2 . Sedangkan dari hasil analisis student worksheet persentase rata-rata pemahaman konsep matematika kelompok mengalami peningkatan sebesar 3,34\% dari siklus 1 ke siklus 2 yaitu dari 78,63\% menjadi $81,97 \%$. Berdasarkan pedoman kualifikasi pada tabel 3 persentase tersebut tergolong dalam kategori tinggi. Namun, pada hasil tes dan hasil student worksheet siklus 1 terdapat perbedaan yang mencolok untuk persentase indikator pemahaman konsep matematika yang pertama dan yang kedua. Persentase indikator pertama pada tes siklus 1 sebesar 93,59\% dan pada student worksheet sebesar 30,77\%. Hal ini disebabkan karena setelah diskusi kelompok diadakan presentasi hasil diskusi. Dengan adanya presentasi hasil diskusi, siswa dapat bertukar pendapat atau mengemukakan hasil diskusi kelompoknya terhadap kelompok lain sehingga siswa dapat mengetahui mana jawaban yang benar. Sedangkan persentase indikator pertama pada tes siklus 1 sebesar 26,67\% dan pada student worksheet sebesar 100\%. Perbedaan ini disebabkan karena tingkat kesulitan soal tes siklus 1 lebih tinggi jika dibandingkan dengan soal pada student worksheet. Persentase ketuntasan belajar siswa juga mengalami peningkatan. Pada siklus 1, Kriteria Ketuntasan Minimal (KKM) yaitu 77 dapat dicapai oleh 11 siswa atau sebesar $42 \%$ dari jumlah siswa, sedangkan pada siklus 2 terdapat 16 siswa yang mencapai Kriteria Ketuntasan Minimal (KKM) atau sebesar 64\% dari jumlah siswa. Berdasarkan hasil pembahasan tersebut, dapat disimpulkan bahwa pembelajaran matematika melalui pendekatan problem posing dengan pembelajaran kooperatif tipe STAD (Student Teams Achievement Divisions) telah mampu meningkatkan pemahaman konsep matematika siswa kelas VIII MTs Ponpes Alkhairaat Paguat pada topik pembelajaran relasi dan fungsi.

\section{KESIMPULAN}

Berdasarkan hasil penelitian yang telah dilakukan di MTS Ponpes Alkhairaat Paguat dapat disimpulkan bahwa Pembelajaran melalui pendekatan problem posing dengan pembelajaran kooperatif tipe STAD (Student Teams Achievement Divissions) yang dapat meningkatkan pemahaman konsep matematika siswa kelas VIII MTs Ponpes Alkhairaat Paguat.

\section{SARAN}

Dari kegiatan penelitian yang telah dilakukan, beberapa saran-saran yang disampaikan adalah:

1. Pembelajaran melalui pendekatan problem posing dengan pembelajaran kooperatif tipe STAD (Student Teams Achievement Divisions) yang telah diterapkan di kelas VIII MTs Ponpes Alkhairaat Paguat dapat dijadikan sebagai alternatif pembelajaran matematika untuk meningkatkan pemahaman konsep siswa.

2. Pembelajaran melalui pendekatan problem posing dengan pembelajaran kooperatif tipe STAD (Student Teams Achievement Divisions) akan dapat meningkatkan pemahaman konsep matematika siswa jika siswa mampu memahami kosa kata yang ada dalam student worksheet yang diberikan. Selain itu, interaksi yang terjadi 
antar siswa adalah interaksi yang mengkaji materi pembelajaran sehingga diperlukan pengawasan yang lebih agar interaksi tersebut dapat terlaksana.

\section{DAFTAR PUSTAKA}

Anita Lie. (2004). Cooperative Learning: Mempraktikkan Cooperative Learning di Ruang-Ruang Kelas. Jakarta: Grasind

Herdian. (2009). Model Pembelajaran Problem Posing. Tersedia di http://herdy07.wordpress.com/2009/04/19/model-pembelajaran problemposing.

Nursalam. (2008). Meningkatkan Aktivitas Belajar Matematika Melalui Metode Problem Posing. Tersedia di http://nursalam-uin.blogspot.com.

Silver, Edward A \& Cai, Jinfa. (1996). An Analysis of Arithmetic Problem Posing by Middle School Students. Journal for Research in Mathematics Education. 27(V). Hlm 523-526

Slavin, Robert E. (2009.) Cooperative Learning: Teori, Riset dan Praktek (terjemahan). Bandung: Nusa Media

S. Nasution. (2005). Berbagai Pendekatan Dalam Proses Belajar Mengajar. Jakarta: Bumi Aksara

Suharsimi Arikunto \& Cepi Safruddin Abdul Jabar. (2004). Evaluasi Program Pendidikan. Jakarta: Bumi Aksara

Sutriyono. (2007). Keefektifan Model Pembelajaran Kooperatif STAD (Student Teams Achievement Divisions) Terhadap Pemahaman Konsep Materi Pokok Bangun Ruang Sisi Datar Siswa Kelas VIII SMP N 3 Dempet Tahun Pelajaran 2006/2007. Abstrak Skripsi. Semarang: Universitas Negeri Semarang.

Wina Sanjaya. (2009). Penelitian Tindakan Kelas. Jakarta: Kencana Prenada Media Group

W.S. Winkel. (1991). Psikologi Pengajaran. Jakarta: Gramedia

Yaya S. Kusumah. (2004). Model Pembelajaran Matematika untuk Meningkatkan Kemampuan Kognitif dan afektif Siswa Sekolah Menengah. Makalah disajikan dalam Seminar Nasional Matematika yang diselenggarakan Universitas Negeri Yogyakarta pada tanggal 12 Oktober 2004 